\title{
Impact of ownership types on R\&D intensity and innovation performance-evidence from transitional China
}

\author{
Da Teng ${ }^{1}$ and Jingtao $\mathrm{Yi}^{2^{*}}$
}

\author{
* Correspondence: \\ yijingtao@ruc.edu.cn \\ ${ }^{2}$ School of Business, Renmin \\ University of China, Beijing 100872, \\ China \\ Full list of author information is \\ available at the end of the article
}

\begin{abstract}
This paper examines the effects of ownership types on firms' R\&D intensity and innovation performance, using a sample of 357,857 Chinese firms from 2005 to 2007.

This study finds considerable divergence among Chinese domestic enterprises in terms of R\&D intensity and innovation performance. We find that firms owned by the central government are the key drivers for firms' R\&D activities, while local government, private and foreign ownerships are negatively related to both R\&D intensity and innovation performance. This paper finds significant divergence within government ownership category and argues that China's institutional changes generate varied government ownership groups with different levels of resource endowment, which in turn influence firms' R\&D activities.
\end{abstract}

Keywords: Ownership, R\&D intensity, Innovation performance, Institutional changes, China

\section{Introduction}

A large number of studies in the management literature have linked ownership with firms' research and development (R\&D) (Molas-Gallart and Tang 2006; Choi et al. 2011) and argued ownership types are crucial to understanding R\&D intensity and innovation performance in both advanced industrialized and transitional economies (Jefferson et al. 2003; Lee and O'Neill 2003; Chen et al. 2014). For instance, Hoskisson et al. (2002) suggested that public pension funds have a long-term viewpoint when making investment decisions, such as R\&D and new product development. Choi et al. (2011) studied 548 listed firms in China and found foreign, state and institutional ownership positively influence firm innovation performance, measured by volume of patent registration.

Despite great progress in assessing the relationship, existing literature studied the association of a firm's ownership with its R\&D activities in a static context without taking the institutional environment into consideration. Many scholars observed the changing institutional environment in China after the economic reform in 1978. For example, researchers discussed the effects of economic reforms on corporate ownership, corporate governance and firm performance (Qian 1996; Qi et al. 2000; Sun et al. 2002; Sun and Tong 2003; Zhang 2015). However, a limited number of researchers studied the effects of

(c) The Author(s). 2017 Open Access This article is distributed under the terms of the Creative Commons Attribution 4.0 International License (http://creativecommons.org/licenses/by/4.0/), which permits unrestricted use, distribution, and reproduction in any medium, provided you give appropriate credit to the original author(s) and the source, provide a link to the Creative Commons license, and indicate if changes were made. 
the changing institutional environment on state-owned enterprises (SOEs) and other domestic firms' R\&D activity. Even fewer studies discussed the divergence of SOEs following the economic reform regarding their R\&D intensity and innovation performance.

Existing studies generally consider government ownership as a universal group (Teng 2012) and found mixed and even contradictory results of the effects of government ownership on firm's R\&D activities. For example, Jefferson et al. (2003) found that Chinese SOEs' managers are more risk-averse compared to managers in private or collective enterprises under complex environments and suggested SOEs as a whole is less likely to select risky R\&D strategy (Zhang et al. 2003). On the other hand, Chang et al. (2006) suggested that government ownership offers firms with long-term corporate aim beyond short-term profit maximization, in turn, has a positive effect on firms' innovation. By addressing such conflicting views, we extend the argument beyond the surface of government ownership and investigate how different levels of government ownership influence a firm's R\&D.

This study addresses these two research gaps and makes two contributions. First, we leverage institutional theory with agency theory in explaining firm's R\&D intensity and innovation performance. A large number of researchers have linked a firm's ownership with its R\&D under agency theory's framework. However, the institutional environment in which the firm is embedded is overlooked. Recent studies have acknowledged the importance of institutions and suggested both formal and informal institutions have capacities to facilitate and constrain firm behavior (Peng et al. 2008). Furthermore, institutions undergo changes over time, both incremental and revolutionary. Thus, it is important to study institutions in transitional economies, not only because institutions are different from developed economies, but also institutions are experiencing huge changes during the transition period.

Second, this paper makes significant contributions by demonstrating how different levels of government influence a firm's R\&D intensity and innovation performance under a transitional institutional background. Previous studies have noted that the Chinese government is involved in varied firm level activities (Luo et al. 2010; Kafouros et al. 2015); however, prior research has considered the government ownership as a whole and neglects variations of different government levels (Wang et al. 2012b). We argue that this stream of research under-theorizes government involvement and offers limited understanding on the differential effects that various levels of government have on a firm's R\&D activities. We adopt the institution-based view (Peng 2003; Peng et al. 2008) and suggest that China's institutional changes (i.e., fiscal reform and SOE reform) rebalanced the resource endowments between central and local governments, which in turn generated various R\&D intensity and innovation performance between firms owned by central and local governments. We provide not only compelling evidence showing state-owned organization can undertake risky $R \& D$ investment, but also striking differences in term of R\&D intensity and innovation performance between central government-owned firms and local government-owned firms. This research thus provides evidence of government ownership diversity and consequently implies different predictions for the innovation performance and R\&D behavior of state owners from the past literature.

\section{Theory and hypotheses}

The prior research adopted agency theory and studied the relationship between ownership and firms' R\&D by addressing the potential conflicts between shareholders and 
managers (Kim et al. 2008; Belloc 2012; Choi et al. 2012). Agency theory views modern corporations as contractual relationships between shareholder and management and asserts that agency problem arises when the desires or goals of shareholder and management conflict due to the separation of ownership and control (Jensen and Meckling 1976). The divergence of interests between shareholders and management hence requires adequate monitoring to discipline managers and ensure they work in the shareholders' interests instead of their own. Researchers have found that both ownership type and structure are vital in shaping organizational R\&D decision making and innovation performance because they affect both willingness and power to invest in this risky strategy (Choi et al. 2011).

Aguilera et al. (2008) however criticized agency theory's under-contextualised nature and argue distinct institutions in which firms are embedded exogenously determined firm's strategic choices. Through addressing agency theory's inability to explain the diversity of corporate governance arrangements across nations, recent studies extend institutional theory and develop an institution-based view of the firm (Peng 2003; Peng et al. 2008). Institution-based view of firm attributes different firm behavior to external institutions (e.g., political regulation and established legitimacy). Institutions, which are defined as the rules of the game (North 1990), have been proved to exhibit formal and informal pressures for firms, and directly affect firms' strategic choices and performance. In other words, institutions determine directly how firms formulate and implement strategy because both formal and informal institutions have capacities to control and constrain firm's resource endowment and consequently influence managerial behavior. Institution-based view of the firm, therefore, complements the "under-socialized" nature of agency theory and states that institutional constraints impel different firm-level strategies and other organizational outcomes. Based on this theoretical premise, we explicate how China's institutional changes altered resource endowment of firms owned by different levels of government in the next section.

\section{The changing institutional environment in China}

Institutions, which are defined as "the rules of the game" (North 1990; Scott 1995), have been proved to exhibit formal and informal pressures for firms and directly affect firms' strategic choices and performance. The institution-based view focuses on the interactions between institutions and firms (Peng and Heath 1996) and asserts firm's strategic choices and performances are the outcomes of such interactions (Peng 2003; Peng et al. 2008). In other words, institutions determine directly how firms formulate and implement strategy because both formal and informal institutions have capacities to control and constrain managerial behavior. Scott (1995) argues that institutions not only impose restrictions by defining legal and cultural boundaries but also support and endow activities and actors. It is, therefore, essential to understanding the mechanism through which the institutions empower different levels of government actors for taking specific actions.

In this paper, we argue that China's formal institutional changes alter the budget constraints faced by different levels of government. "Soft budget constraint" is an important concept to understand underperformed enterprises in transition economies (Kornai 1992; Kornai et al. 2003). "Soft budget constraint" arises when an unprofitable enterprise is bailed out by the government or other creditors. In other words, firm's budget 
constraint is "softened" by infusion of additional resources when it faces financial difficulties (Maskin 1999). SOEs can count on government's support to survive even if they suffer from chronic losses. "Soft budget constraint" has been adopted to explain SOEs' socio-political oriented objectives because resource reallocation activity as continued subsidies to loss-making SOEs has prompted macroeconomic stability.

China's formal institutional changes (i.e., economic reforms) started in 1978. By decentralizing control, economic reform has made local government more responsive to an enterprise's performance by enjoying the benefits and bearing the risks (Qi 1995). Furthermore, fiscal reform that began in 1993 intervened in the allocation of resources and created different budget constraints between central and local governments. China's fiscal reform changed the way of how revenue is divided between different levels of governments through the "tax-sharing" system implemented in 1994. The new system altered the fiscal relationships among the central, provincial and municipal governments and was based on fixed types of revenue going to certain levels of government and certain taxes being split into fixed terms between local and central government. Local governments (i.e., provincial and municipal) thus had authority over local expenditures and signed fixed-term fiscal contracts with the central government.

The fiscal reform rebalanced revenue and expenditure allocations between central and local governments and re-centralised economic management and compensated central government's revenue shortfall (Zhang and Zou 1998; Zhang 1999). As a consequence, the budget constraint for local government became harder (Pei 2002). Before fiscal reform, benefitting from the soft budget constraints, local government received sufficient financial resources and improved local economic development before 1994. After 1994, central government occupied more than $50 \%$ of national fiscal revenue, which largely strengthened macro-control by the central government. Due to the introduction of the tax sharing system, fiscal transfers have been limited across all sub-national levels of government (Qian and Roland 1998). Therefore, Pei (2002) stated that local governments and their officials resorted to every means (e.g., unscrupulous borrowing) to "buffer" the shortfalls of funds needed. In short, the fiscal reforms of 1994 tightened the fiscal budget constraints of local level governments, while expanding the resources available to central state authorities.

These institutional changes, therefore, produced two groups of government owners with different resources endowments (i.e., budget constraints) when supporting SOEs.

Facing harder budget constraints, local governments often abandoned SOEs as a mean to establish mixed ownership enterprises and avoid political punishment for supporting failing SOEs. In sharp contrast to the predicament of the local government regarding their SOEs, the central government has a much greater command of resources and remains strong over these SOEs in sectors often considered as the critical commanding heights of the economy.

The following hypothesis development section explains in detail how such government ownership diversity leads to different predictions on R\&D intensity and innovation performance.

\section{Hypothesis development}

\section{State ownership concentration and firms' innovation: agency theory perspective}

According to agency theory, large shareholders play a critical role in firms' decision making because they have both the incentive and power to ensure that 
management operates in their interest (Tihanyi et al. 2003). Large shareholders usually have their representatives serve on the board of directors, so they can influence managerial decisions and intervene in the firm's operations (Chen et al. 2011). Furthermore, the nature of large shareholdings is associated with long-term economic performance. Unlike small shareholder's financial risk that can be diversified away easily, large-block shareholding implies a long-term interest horizon.

$R \& D$ is a high risk-high return strategy and does not yield short-term returns. Unlike managers who will be reluctant to invest in long-term and risky $R \& D$ because their compensation and career are conditioned by short-term financial performance, large shareholders have a long-term interest and hence tend to support R\&D (Wright et al. 1996). For example, Zhang et al. (2007) stated that foreign investors tend to support $R \& D$ activities when they have a majority ownership in international joint ventures in emerging economies. Choi et al. (2011) suggested that large shareholders in Chinese listed firms prefer long-term investment projects, such as $R \& D$ in order to enhance their stability in this country. Based on the above discussion, it is hypothesized that:

Hypothesis 1a State ownership concentration will be positively related to the R\&D intensity in transitional China.

Owning a larger stock makes the return on the company's investment more significant for the large shareholder, hence a large number of researchers have suggested that large shareholders have both the incentives and power to restrain selfserving behaviour of managers (Hoskisson et al. 2002; Tihanyi et al. 2003). The large shareholder has enough voting control to put pressure on the management to bring about a change they feel will be beneficial. Their presence among the firm's investors provides an important driver of "good" corporate governance and in turn, produces efficiency gains and improvement in performance.

Meanwhile, many studies have indicated that concentrated shareholding may create a trade-off between incentives and entrenchment (La Porta et al. 2000) and lead to principal-principal problems (Tan and Wang 2007). Large shareholders use their voting power to consume corporate resources or to enjoy corporate benefits at the expense of minority shareholders and eventually generate worse performance (Young et al. 2008). In order to solve this problem, the Chinese government established the State-Owned Assets Supervision and Administration Commission (SASAC) in order to simplify the complex agency relationships among different levels of government, government officials and managers. This institutional evolution highlighted governing the function of SASAC. Being the large and ultimate shareholder, researchers have found that SASAC offers effective monitoring over the managers and affect firm performance more positively (Naughton 2008; Wang et al. 2012a). According to the above discussion, we expect a positive relationship between state ownership concentration and innovation performance. It is hypothesized that:

Hypothesis 1b State ownership concentration will be positively related to the innovation performance in transitional China. 


\section{Ownership types and firms' innovation: institutional theory perspective}

Institutional theory focuses on the interaction between institutions and organizations and proposes that firms are pressured to react and adapt to institutional constraints.

Government ownership: soft budget constraints China's formal institutional reforms changed the rules of the disposition of locally collected revenue. First, the institutional changes endowed central government-owned SOEs with greater resources and more favorable policies (Sheng et al. 2011). In addition, China's SOE reform pushed clear signal to privatize local government-owned SOEs while maintaining and strengthening the strategic position and legitimacy of central government-owned SOEs. In contrast, fiscal budget constraints for local government became relatively harder due to the declining local revenues and limited inter-governmental budgetary transfers (Qian and Roland 1998). According to Montinola et al. (1995) and Chen et al. (2014), harder budget constraints also appeared in the financial channel, which restricted local government's ability to borrow from the central government-owned banks.

Previous literature indicated that resource availability is critical for R\&D intensity and innovation performance (Chen et al. 2014; Zhou et al. 2016). R\&D is a long horizon investment and it may take a long term before the payoffs are realized. Resource availability provides a firm with slack, which allows an organization to adapt internal or external pressures for adjustment or to initiate changes in strategy with respect to the external environment (Cyert and March 1963). Proponents of slack resource assert that slack allows firms to experiment and hence encourage innovation in the long-term (Nohria and Gulati 1997; Greve 2003). For instance, Souder and Shaver (2010) suggested that firms that organizations with sufficient resources are likely to support attractive long horizon investment projects. Nohria and Gulati (1996) and Chen and Miller (2007) also indicated that firms with abundant slack resources are more likely to foster uncertain R\&D projects than firms with little accumulated slack resources. For transitional economies, $\mathrm{Li}$ et al. (2013) SOEs can afford to engage in innovation due to resource slack. Zhou et al. (2016) also found that state ownership enables firms to gain more resources to invest in $R \& D$ activities.

China's institutional changes strengthened central government-owned SOEs' competitive position by empowering them with legitimacy and resources. We thus propose that central government ownership enables SOEs to gain more resources to invest in R\&D activities. In transitional economies, the government controls most of the key resources (Musacchio and Lazzarini 2014). R\&D is encouraged at central government-owned SOEs because its ownership nature secures capital supply and government subsidies (Zhou et al. 2016). Sufficient resources buffer the organization from the uncertain success of those risky projects (Stan et al. 2014). On the other hand, harder budget constraints (i.e., insufficient resources) provide local government owned enterprises with less or no slack resource and thus discourage investment in risky R\&D project. Thus, we argue that SOEs affiliated by different levels of government would adopt varied R\&D strategies according to the budget constraints. The above discussions lead to the following hypotheses:

Hypothesis 2a Central government ownership will be positively related to the R\&D intensity in transitional China. 
Hypothesis 2b Local government ownership will be negatively related to the R\&D intensity in transitional China.

While many scholars state that firms require surplus resources to grow, opponents counter that slack resources may encourage wasteful investment in innovation activities. The standpoint of such criticism arises from agency theory. The separation of ownership and management leads managers to discover themselves with discretionary control over the funds that shareholders invest. As a result, managers may engage in opportunistic behavior while principals do not have sufficient and quality information to monitor their performance (Jensen and Meckling 1976). Managers may squander the slack resources by expanding the size of the firm (empire building), even when the expansion is inefficient. A large shareholder can be an effective actor to control the agency problems. As discussed, large block shareholders play an effective corporate governance role because they have both the incentive and power to discipline the management. Ownership concentration can constrain the consumption of perquisites by managers and thus enhance corporate performance.

Since the late 1990s, SOEs owned by the central and local government have developed distinctly different ownership structures due to institutional changes (i.e., fiscal and SOE reforms). The institutional changes restructured and privatized SOEs based on a "grasp the large, release the small" strategy - retaining government control of large enterprises that operate in strategically important sectors and releasing small and medium-sized firms that are operating in unimportant sectors (Liu et al. 2006). For large central government-owned SOEs, the government remains majority shareholding and exerts influences through SASAC over more than 100 firms. Because of the majority shareholding, the Chinese central government and its representatives would effectively monitor the management in order to ensure slack resources are used productively. Wang et al. (2012a) praised SASAC for its positive role in monitoring the management at central government-owned SOEs.

On the other hand, many local governments had lost effective control over SOEs and surrendered control to management. Furthermore, it is difficult for local government to exercise their influence due to information asymmetry. Thus, managers in local government-owned firms use resources to fulfil their personal agendas rather than work for state owners' interests. This view is consistent with evidence that local governments are reluctant to directly intervene business operation in partially privatized SOEs because the formal institutional setting is promoting a socialized market economy with a cut-off link between the government and the firm (Liu et al. 2006). Therefore, we expect firms with local government ownership should unitize resources less productively. We then propose:

Hypothesis 3a Central government ownership will be positively related to innovation performance in transitional China;

Hypothesis 3b Local government ownership will be negatively related to innovation performance in transitional China.

Private ownership: legitimacy and intellectual property protection Institutions determine directly how firms formulate and implement strategy because both formal and 
informal institutions have capacities to control and constrain managerial behavior. It is well documented that firm's strategies are subjected to the under-developed institutions in transition economies (Peng and Heath 1996). Previous studies suggest that firms can gain competitive advantage if they are able to move beyond institutional constraints (Peng et al. 2008).

Private-owned enterprises (POEs) are generally considered to be entrepreneurial and are keen to take risky projects. POEs are, however, confronted with the legitimacy issue in transitional economies, such as China. Though the institutional changes have recognised the legitimacy of private ownership, government ownership still remains its dominance position in China. It is very difficult for private firms to obtain critical resources, such as capital, human resources and marketing channels (Li and Putterman 2008; Yam et al. 2004; Yiu et al. 2013;) and this ownership category is placed at the bottom of the government's priority list. Yiu et al. (2013), for instance, pointed out private-owned firms in China are facing with financing difficulty because the central government has strengthened the macro regulation and control over this ownership regime. Zeng et al. (2010) suggested that facing limited resources and more uncertainties and barriers, innovation in private firms would become inefficient. Therefore, Li and Xia (2008) suggested that compared to SOEs, privately-owned firms trend to emphasis on short-term riskfree investment due to insufficient human and capital resources, weak marketing channels, and poor distribution networks.

In addition to that, the under-developed institutions have impeded private firm's engagement in $R \& D$ and innovation. Compared to developed economies, transition economies have far less sophisticated institutional framework, with poorly conceived or ineffectively enforced property right and weakly developed capital market (Estrin et al. 2009; Lejeune 2014; Meyer and Peng 2016). As a basic rule in a developed market economy, intellectual property rights (IPRs) protection affects firms' incentives for investments in innovation (La Croix and Konan 2002). Strong intellectual property regimes would support R\&D and innovation (Pisano 2006). The effective protection of intellectual property rights through patent laws and related enforcements reduces the risk for companies' innovation output being imitated by competitors. Yueh (2009) has found that the increasingly matured IPRs system increases the propensity to innovate because it secures returns on an innovation and provides protection against expropriation. In other words, weak IPRs protection in transitional economies, such as China inhibits firm's incentive in conducting $R \& D$ activities since the provision of less security of intellectual property (Davidson and Segerstrom 1998). Based on the above discussion, we argue that privately-owned firms are not the main players in technological innovation activities in China. Privately-owned firms would concentrate on less technical-sophisticated production and their innovation activities are less efficient. Hence, we propose:

Hypothesis 4a Private ownership will be negatively related to the R\&D intensity in transitional China.

Hypothesis 4b Private ownership will be negatively related to the innovation performance in transitional China. 


\section{Data and method \\ Data}

The data that are used in our study derive from the National Bureau of Statistics of China (NBS) and span the period 2005-2007. The NBS has compiled the data from the Annual Report of Industrial Enterprise Statistics and attempted to maintain consistency and accuracy in data collection and process in terms of time, region and industry (Zhou and Li 2008; Yi et al. 2013). The Census data contain comprehensive information regarding a firm's operational profile, i.e., total output, new product output, exports, valued added, employment, ownership structure, and its financial profile, i.e., total assets, total debts, owner's equity, paid-up capital. Our sample spans around 30 two-digit industries in manufacturing sector, such as food, beverage, textile, electronic products, transport equipment, ordinary machinery, and special purposes equipment, and all 31 provinces and municipalities in China. Recent studies have used the census data for business research in a variety of areas due to the quality of data (Zhang et al. 2007; Zhou and Li 2008). We set up our sample in two steps. First, we carefully examine firm name, identifier code, founding year, geographical code, and industry code and drop coding errors and missing values. Second, we pay attention to organizational changes (i.e., mergers and acquisitions, structural changes) and ownership structures and drop firms that have experienced structural adjustments and firms with mixed ownership patterns. This process finally produces a dataset of 357,857 firms for 2005-2007.

The dataset presents an appropriate setting that allows us to test the relationship between ownership and R\&D intensity/innovation performance under the investigation. In the dataset, the firms and their R\&D expenditures and new product sales can be traced over a continuous time given the sample period. The financial information about paid-up capital consists of state capital, collective capital, private capital, and foreign capital and the dataset includes the registration codes regarding ownership types. We can examine the role of ownership precisely through double-checking capital share information with registered categories. Table 1 summarizes ownership, R\&D intensity and innovation performance information in the final dataset. We find that central SOEs spend much more on R\&D activities than other types of firms and have higher innovation performance in terms of new product share. POEs lag far behind central and local SOEs in both R\&D expenditures and innovation outputs. The picture clearly demonstrates that central SOEs play a leading role in innovation aspects even within SOEs in transitional China and remains unchanged over the sample period. Since the Census dataset covers all manufacturing industries, we can take a closer look at the industrial composition. Table 2 summarizes state stock concentration, R\&D expenditures, and innovation performance by two-digit industry. State stock concentration in industries of tobacco, printing and record medium, beverage, transport equipment, special purposes equipment, and medicals and pharmaceuticals are among the highest. Telecommunications, computer and electronics, and instruments and meters perform much better than other industries in both R\&D expenditures and innovation outputs. Thus, heterogeneous industries significantly account for the part of variance in the relationship between ownership concentration and innovation behavior.

\section{Measures}

Our dependent variables are $R \& D$ intensity and innovation performance of a firm respectively and our main independent variables are ownership concentration and 
Table 1 Data description by years and ownership types

\begin{tabular}{llcc}
\hline & Ownership Type & R\&D intensity & Innovation performance \\
\hline 2005 & Central SOEs & 1.857 & 0.116 \\
& Local SOEs & 0.626 & 0.041 \\
2006 & POEs & 0.329 & 0.029 \\
& Central SOEs & 3.249 & 0.117 \\
& Local SOEs & 0.724 & 0.044 \\
& POEs & 0.449 & 0.034 \\
& Central SOEs & 4.075 & 0.121 \\
& Local SOEs & 1.034 & 0.049 \\
Average & POEs & 0.591 & 0.033 \\
& Central SOEs & 2.899 & 0.118 \\
& Local SOEs & 0.746 & 0.044 \\
& POEs & 0.471 & 0.032 \\
\hline
\end{tabular}

$R \& D$ intensity is the ratio of $R \& D$ expenditures to total sales; innovation performance is the ratio of new product sales over total sales

ownership types, including central government ownership, local government ownership, and private ownership. Table 3 provides the definition of these variables.

Dependent variables. R\&D intensity is measured by R\&D expenditures divided by total sales; and innovation performance is measured by new product sales divided by total sales. A large number of studies have used $R \& D$ expenditures divided by firm sales as a measure of $R \& D$ intensity that can be viewed as the input of firms' $R \& D$ activities (Lee and O'Neill 2003; Zhang et al. 2007). Sales of new product sales has been used as an innovation performance measure (Berchicci 2013; Cassiman and Veugelers 2006; Escribano et al. 2009; Love et al. 2009; Kafouros et al. 2015; Tsai 2009; Zhou et al. 2016) because it represents the success of new or significantly improved products in the market. The census data provide information on revenue from new or significantly improved products that can be viewed as the output of firms' R\&D activities.

Independent variables. State ownership concentration is measured by state stock concentration that is the share of state-owned assets to total assets in accordance with the registration code of state ownership. Our dataset provides information about registration codes that categorize ownership (i.e., types of state-owned, privately owned, and foreign-owned types). In this way, we can ensure the consistency of the measure with the block shareholder, i.e., the power perspective. Lee and O'Neill (2003) show that stock concentration is a significant determinant of innovation behavior. For transitional China, state shares are often used in studies of firm's R\&D (Choi et al. 2011). Similarly, private ownership concentration is measured by private stock concentration that is the share of private-owned assets to total assets in accordance with the registration code of state ownership. Given institutional changes, we also include three variables to account for the role of ownership types. In addition to registration codes that categorize ownership, our dataset provides information about affiliation codes that distinguish the government levels to which a firm is affiliated (i.e., levels of central government, provincial government, prefectural and city government, county government, and township and village government). Thus, we can categorize state ownership types in different levels and also other ownership types without requiring the minimal level of capital share. Central government ownership is measured by central SOEs, a dummy variable that is 
Table 2 State ownership concentration, R\&D intensity and innovation performance by industry

\begin{tabular}{|c|c|c|c|}
\hline Two-digit industry & State Stock & R\&D intensity & Innovation performance \\
\hline 13. Food Processing & 0.051 & 0.345 & 0.018 \\
\hline 14. Food Production & 0.049 & 0.415 & 0.051 \\
\hline 15. Beverage Production & 0.074 & 0.344 & 0.034 \\
\hline 16. Tobacco Processing & 0.520 & 1.781 & 0.029 \\
\hline 17. Textile & 0.016 & 0.210 & 0.026 \\
\hline 18. Garments and Other Fibre Products & 0.011 & 0.074 & 0.032 \\
\hline 19. Leather, Furs, Down, and Related Products & 0.005 & 0.095 & 0.036 \\
\hline 20. Timber Processing & 0.022 & 0.070 & 0.021 \\
\hline 21. Furniture Manufacturing & 0.012 & 0.138 & 0.032 \\
\hline 22. Papermaking and Paper Products & 0.024 & 0.146 & 0.016 \\
\hline 23. Printing and Record Medium Reproduction & 0.139 & 0.266 & 0.024 \\
\hline 24. Cultural, Educational, and Sports Goods & 0.012 & 0.140 & 0.038 \\
\hline 25. Petroleum Refining and Coking & 0.048 & 0.769 & 0.017 \\
\hline 26. Raw Chemical Materials and Chemical Products & 0.041 & 1.002 & 0.038 \\
\hline 27. Medical and Pharmaceutical Products & 0.055 & 2.833 & 0.097 \\
\hline 28. Chemical Fibre & 0.023 & 0.645 & 0.039 \\
\hline 29. Rubber Products & 0.026 & 0.410 & 0.032 \\
\hline 30. Plastic Products & 0.016 & 0.242 & 0.028 \\
\hline 31. Non-metal Mineral Products & 0.044 & 0.269 & 0.030 \\
\hline 32. Smelting and Pressing of Ferrous Metals & 0.029 & 0.255 & 0.021 \\
\hline 33. Smelting and Pressing of Non-ferrous Metals & 0.038 & 0.858 & 0.034 \\
\hline 34. Metal Products & 0.020 & 0.323 & 0.026 \\
\hline 35. Ordinary Machinery & 0.034 & 0.629 & 0.043 \\
\hline 36. Special Purposes Equipment & 0.056 & 1.808 & 0.072 \\
\hline 37. Transport Equipment & 0.063 & 1.145 & 0.056 \\
\hline 39. Electric Equipment and Machinery & 0.026 & 1.280 & 0.060 \\
\hline 40. Telecommunications, Computer and other Electronics & 0.031 & 4.378 & 0.107 \\
\hline 41. Instruments and Meters & 0.051 & 4.089 & 0.116 \\
\hline 42. Arts and Grafts Products & 0.018 & 0.379 & 0.039 \\
\hline 43. Waste Resources and Materials Recycling, Processing & 0.015 & 0.251 & 0.014 \\
\hline Average across Manufacturing & 0.035 & 0.768 & 0.040 \\
\hline
\end{tabular}

The numbers in the first column are two-digit industry codes used by the National Bureau of Statistics of China

coded one if the firm is state-owned and affiliated at the state level of government. Local government ownership is measured by local SOEs, a dummy variable that is coded one if the firm is state-owned and affiliated at the local level of government (i.e., levels of government affiliation lower than the state level). Government ownership in a firm is often considered as an institutional capital (Luo and Yao 2006). Private ownership is measured by POEs, a dummy variable that is coded one if the firm is privately owned.

Control variables. We also control for a number of variables that might account for variations in R\&D behavior of firms. Firm size is measured by the natural log of total number of employees in this firm (Love et al. 2009). Firm age is measured by the number of years since it was founded (Choi et al. 2011). Foreign ownership is measured by FIEs, a dummy variable that is coded one if the firm is foreign-owned. Foreign 
Table 3 Definition of variables

\begin{tabular}{ll}
\hline Dependent variables & Definition \\
R\&D intensity & Ratio of R\&D expenditure to total sales \\
Innovation performance & Ratio of new product sales to total sales \\
Independent variables & Ratio of state-owned assets to total assets if a firm is state-owned \\
State stock concentration & Ratio of private-owned assets to total assets if a firm is private-owned \\
Private stock concentration & Dummy, equals to 1 if state-owned and affiliated at the state level \\
Central SOEs & of government \\
Local SOEs & Dummy, equals to 1 if state-owned and affiliated at the local level \\
of government \\
Control variables & Dummy, equals to 1 if private-owned \\
Firm size & Number of employees in logarithm \\
Firm age & Number of years since establishment \\
Foreign ownership & Dummy, equals to 1 if foreign-owned \\
Leverage & Ratio of total debts to total assets \\
Employee training & Ratio of expenditure on employee training to total sales \\
Capital intensity & Ratio of total fixed assets to total employees \\
Return to assets & Ratio of total profits to total assets in a lagged period \\
Industry dummy & Dummy, equals to 1 if affiliated at the corresponding two-digit industry \\
Region dummy & Dummy, equals to 1 if located at the corresponding province-level region \\
Year dummy & Dummy, equals to 1 if associated with the corresponding year \\
\hline
\end{tabular}

investors with considerable equity stakes are supposed to play significant governance and resource roles (Filatotchev et al. 2008). Leverage is measured as total debts divided by total assets (Lee and O'Neill 2003). Employee training is measured as expenditures on employee training divided by total sales (Ballot et al. 2006). Employee training includes developing skills and capabilities and learning new technologies and methods and is oriented to enhance human capital in a firm. Capital intensity is measured by total fixed assets per employee (Love et al. 2009). Return to assets is measured as total profits divided by total assets (Chen and Miller 2007). In addition, two-digit industry dummies are included to control for industrial differences that may influence variations in innovation behavior of firms. Given that China is characterized by significant variations across regions in terms of economic development and degree of openness, regional dummy variables are included to control for the characteristics of the province-level region where the firm is located. Year dummies are annual time effects reflecting temporal variations in innovation behavior, and included to capture the influence of government policies at a particular year and other time-varying factors on innovation behavior of firms.

\section{Model specification}

The dependent variables, R\&D intensity and new product share, have three peculiar characteristics. The first is that both measures range between 0 and 1 and are censored because they can only be zero or positive (Leiponen and Helfat 2010). Second, many 
observations have a value equal to zero for the dependent variables (Wiersema and Bowen 2008). Third, the equations for both measures imply nonnegative predicted values, which has sensible partial effects over a wide range of the explanatory variables (Wooldridge 2013). Given these reasons, Tobit models are used to correct for such limited dependent variables (Tobin 1958), allowing us to estimate hypotheses more appropriately. The tobit model has the following form:

$$
y_{\mathrm{it}}^{*}=\mathrm{O}_{\mathrm{it}} \alpha+\mathrm{X}_{\mathrm{it}} \beta+\mathrm{Z}_{\mathrm{it}-1} \gamma+\lambda_{\mathrm{j}}+\lambda_{\mathrm{k}}+\lambda_{\mathrm{t}}+\varepsilon_{\mathrm{it}}
$$

where $y_{\mathrm{it}}^{*}$ is an unobserved latent variable representing innovation variable that is only realized as the actual one, $y_{i t}$ if it falls between zero and one, $\mathrm{O}_{i t}$ are ownership variables that include ownership concentration and types, $\mathrm{X}_{\mathrm{it}}$ are control variables that are exogenous, including firm attributes, i.e., firm age, firm size, capital intensity, leverage, and employee training, $Z_{i t-1}$ are control variables that are probably endogenous, i.e., return to assets, $\lambda_{\mathrm{j}}, \lambda_{\mathrm{k}}$ and $\lambda_{\mathrm{t}}$ are industry, region and time fixed effects respectively, and $\varepsilon_{\text {it }}$ is the error term which is independently and identically distributed across time and firms. The specification implies that even though many observations have an identical score of zero or one on innovation variable, they can obtain different scores on the latent variable. The relationship between the observed and latent variables is defined as:

$$
\left\{\begin{array}{l}
y_{i t}=y_{i t}^{*} \text { if } 0<y_{i t}^{*}<1 \\
y_{i t}=0 \text { if } y_{i t}^{*} \leq 0 \\
y_{i t}=1 \text { if } y_{i t}^{*} \geq 1
\end{array}\right.
$$

where zero and one are the threshold for censoring.

We follow Chen and Miller (2007) to lag return to assets one year in the specification to control for possible endogeneity biases in the regression analysis, provided that our sample spans three years, since there might also be a reverse effect from innovation behavior to return to assets. This treatment makes endogenous variables predetermined and unlikely to be correlated with the error term. Furthermore, we inspected the variance inflation factors (VIFs) of the variables to assess the effect of multicollinearity. The VIF ranges from 1.00 to 1.58 , lower than the acceptable level of 10, indicating that multicollinearity did not have an undue influence on the estimates (Neter et al. 1985). In addition, we estimate Huber-White's robust standard error to cope with the possible threat of heteroskedasticity (White 1980).

\section{Findings}

\section{Result analyses}

Table 4 provides descriptive statistics for the variables of the study. All correlations among the independent variables are low except for the correlation between state stock concentration and local SOEs and the one between private stock concentration and POEs.

Tables 5 and 6 present the results from hierarchical moderated regression of R\&D intensity and innovation performance respectively. The baseline model includes control variables only. Other models incorporate ownership concentration and types separately to examine the relationship between ownership and innovation activities. The regression results support all the hypotheses with respect to the relationships between ownership and firms' innovation activities. The regression results for control variables show 


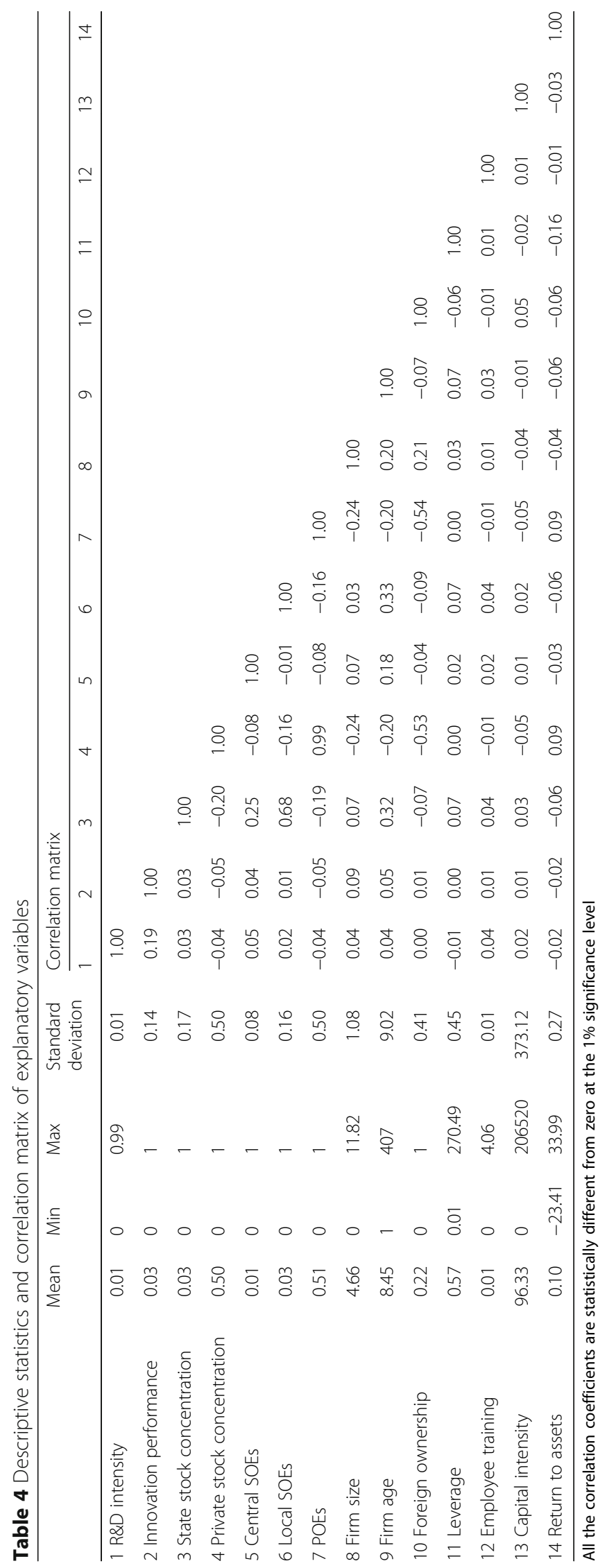


Table 5 Hierarchical analyses of ownership and R\&D intensity: Tobit estimation

\begin{tabular}{|c|c|c|c|}
\hline & \multicolumn{3}{|c|}{ R\&D expenditure/Sales } \\
\hline & Benchmark & Model 1 & Model 2 \\
\hline \multicolumn{4}{|l|}{ Independent variables } \\
\hline \multirow[t]{2}{*}{ State stock concentration } & & $0.008^{* * *}$ & \\
\hline & & $(0.001)$ & \\
\hline \multirow[t]{2}{*}{ Private stock concentration } & & $-0.006^{* * *}$ & \\
\hline & & $(0.000)$ & \\
\hline \multirow[t]{2}{*}{ Central SOEs } & & & $0.022^{* * *}$ \\
\hline & & & $(0.001)$ \\
\hline \multirow[t]{2}{*}{ Local SOEs } & & & $0.002^{* *}$ \\
\hline & & & $(0.001)$ \\
\hline \multirow[t]{2}{*}{ POEs } & & & $-0.006^{* * *}$ \\
\hline & & & $(0.000)$ \\
\hline \multicolumn{4}{|l|}{ Control variables } \\
\hline \multirow[t]{2}{*}{ Firm size } & $0.014^{* * *}$ & $0.013^{* * *}$ & $0.013^{* * *}$ \\
\hline & $(0.000)$ & $(0.000)$ & $(0.000)$ \\
\hline \multirow[t]{2}{*}{ Firm age } & $0.000^{* * *}$ & $0.000^{* * *}$ & $0.000^{* * *}$ \\
\hline & $(0.000)$ & $(0.000)$ & $(0.000)$ \\
\hline \multirow[t]{2}{*}{ Foreign ownership } & $-0.005^{* * *}$ & $-0.009^{* * *}$ & $-0.009^{* * *}$ \\
\hline & $(0.000)$ & $(0.000)$ & $(0.000)$ \\
\hline \multirow[t]{2}{*}{ Leverage } & $-0.013^{* * *}$ & $-0.013^{* * *}$ & $-0.013^{* * *}$ \\
\hline & $(0.000)$ & $(0.000)$ & $(0.000)$ \\
\hline \multirow[t]{2}{*}{ Employee training } & $0.348^{* * *}$ & $0.340^{* * *}$ & $0.338^{* * *}$ \\
\hline & $(0.002)$ & $(0.002)$ & $(0.002)$ \\
\hline \multirow[t]{2}{*}{ Capital intensity } & $0.000^{* * *}$ & $0.000^{* * *}$ & $0.000^{* * *}$ \\
\hline & $(0.000)$ & $(0.000)$ & $(0.000)$ \\
\hline \multirow[t]{2}{*}{ Return to assets } & $-0.002^{* * *}$ & $-0.001^{* *}$ & $-0.001^{* *}$ \\
\hline & $(0.001)$ & $(0.000)$ & $(0.000)$ \\
\hline Industry dummy & Yes & Yes & Yes \\
\hline Region dummy & Yes & Yes & Yes \\
\hline Year dummy & Yes & Yes & Yes \\
\hline $\mathrm{N}$ & 465587 & 465587 & 465587 \\
\hline x2-statistic & $41250^{* * *}$ & $41796^{* * *}$ & $41984^{* * *}$ \\
\hline Log likelihood & 174.53 & 447.59 & 541.42 \\
\hline
\end{tabular}

** and *** are significantly different from zero at the $5 \%$ and $1 \%$ level respectively

that determinants of $R \& D$ intensity and innovation performance vary significantly. Although firm size, firm age, foreign ownership, and capital intensity have similar impacts on both R\&D intensity and innovation performance significantly, the remaining determinants behave quite differently. For instance, employee training expenditures have positive and significant impacts on R\&D intensity without significant influences on innovation outputs. This finding might raise the concern with the quality of employee training particularly with respect with innovative capability. In addition, return on assets has a significant and positive effect on innovation performance but a negative effect on R\&D intensity. In emerging economies, $R \& D$ activities may not strictly guided by profit-maximization principles but innovation success is highly reliant upon turnovers from innovation. 
Table 6 Hierarchical analyses of ownership and innovation performance: Tobit estimation

\begin{tabular}{|c|c|c|c|c|c|}
\hline & \multicolumn{5}{|c|}{ New product sales/Sales } \\
\hline & Benchmark & Model 1 & Model 2 & Model 3 & Model 4 \\
\hline \multicolumn{6}{|l|}{ Independent variables } \\
\hline \multirow[t]{2}{*}{ State stock concentration } & & $0.039 * * *$ & $0.028^{* * *}$ & & \\
\hline & & $(0.011)$ & $(0.011)$ & & \\
\hline \multirow[t]{2}{*}{ Private stock concentration } & & $-0.091^{* * *}$ & $-0.081^{* * *}$ & & \\
\hline & & $(0.005)$ & $(0.005)$ & & \\
\hline \multirow[t]{2}{*}{ Central SOEs } & & & & $0.103^{* * *}$ & $0.062^{* * *}$ \\
\hline & & & & $(0.019)$ & $(0.019)$ \\
\hline \multirow[t]{2}{*}{ Local SOEs } & & & & $-0.019^{*}$ & $-0.022^{* *}$ \\
\hline & & & & $(0.012)$ & $(0.012)$ \\
\hline \multirow[t]{2}{*}{ POEs } & & & & $-0.093^{* * *}$ & $-0.082^{* * *}$ \\
\hline & & & & $(0.005)$ & $(0.005)$ \\
\hline \multicolumn{6}{|l|}{ Control variables } \\
\hline \multirow[t]{2}{*}{ R\&D intensity } & & & $5.410^{* * *}$ & & $5.405^{* * *}$ \\
\hline & & & $(0.091)$ & & $(0.091)$ \\
\hline \multirow[t]{2}{*}{ Firm size } & $0.168^{* * *}$ & $0.163^{* * *}$ & $0.155^{* * *}$ & $0.163^{* * *}$ & $0.155^{* * *}$ \\
\hline & $(0.002)$ & $(0.002)$ & $(0.002)$ & $(0.002)$ & $(0.002)$ \\
\hline \multirow[t]{2}{*}{ Firm age } & $0.004^{* * *}$ & $0.003^{* * *}$ & $0.003^{* * *}$ & $0.003^{* * *}$ & $0.003^{* * *}$ \\
\hline & $(0.000)$ & $(0.000)$ & $(0.000)$ & $(0.000)$ & $(0.000)$ \\
\hline \multirow[t]{2}{*}{ Foreign ownership } & $-0.018^{* * *}$ & $-0.072^{* * *}$ & $-0.059^{* * *}$ & $-0.074^{* * *}$ & $-0.061^{* * *}$ \\
\hline & $(0.005)$ & $(0.006)$ & $(0.006)$ & $(0.006)$ & $(0.006)$ \\
\hline \multirow[t]{2}{*}{ Leverage } & $-0.006^{* *}$ & $-0.007^{* * *}$ & -0.003 & $-0.006^{* *}$ & -0.003 \\
\hline & $(0.002)$ & $(0.002)$ & $(0.002)$ & $(0.002)$ & $(0.002)$ \\
\hline \multirow[t]{2}{*}{ Employee training } & 0.245 & 0.150 & -0.229 & 0.154 & -0.221 \\
\hline & $(0.294)$ & $(0.302)$ & $(0.572)$ & $(0.304)$ & $(0.567)$ \\
\hline \multirow[t]{2}{*}{ Capital intensity } & $0.000^{* * *}$ & $0.000^{* * *}$ & $0.000^{* * *}$ & $0.000^{* * *}$ & $0.000^{* * *}$ \\
\hline & $(0.000)$ & $(0.000)$ & $(0.000)$ & $(0.000)$ & $(0.000)$ \\
\hline \multirow[t]{2}{*}{ Return to assets } & $0.023^{* * *}$ & $0.034^{* * *}$ & $0.031^{* * *}$ & $0.033^{* * *}$ & $0.030^{* * *}$ \\
\hline & $(0.009)$ & $(0.008)$ & $(0.008)$ & $(0.008)$ & $(0.008)$ \\
\hline Industry dummy & Yes & Yes & Yes & Yes & Yes \\
\hline Region dummy & Yes & Yes & Yes & Yes & Yes \\
\hline Year dummy & Yes & Yes & Yes & Yes & Yes \\
\hline N & 465587 & 465587 & 459698 & 465587 & 459698 \\
\hline X2-statistic & $42120^{* * *}$ & $42524^{* * *}$ & $44779^{* * *}$ & $42539^{* * *}$ & $44783^{* * *}$ \\
\hline Log likelihood & -123125 & -122923 & -116502 & -122916 & -116500 \\
\hline
\end{tabular}

$*^{* * *}$ and ${ }^{* * *}$ are significantly different from zero at the $10 \%, 5 \%$ and $1 \%$ level respectively

For state ownership concentration, the result is consistent with Hypothesis 1a and the coefficient is positive and statistically significant at the $1 \%$ level, indicating that firms with more state ownership tended to have a higher level of R\&D intensity than firms with less state ownership. State ownership concentration is also positively related to innovation performance, and the coefficient is statistically significant at the $1 \%$ level, suggesting that state ownership is beneficial for new product's production and sales and supporting Hypothesis $1 \mathrm{~b}$. We have found that state ownership concentration increases turnovers from new or significantly improved products. But since we have also found 
that state ownership concentration increases $R \& D$ investment, the question emerges concerning whether state ownership concentration increases or decreases the effectiveness of a firm in converting any given input of $R \& D$ expenditure into innovation output. To test whether state ownership concentration improves the effectiveness of the firm in generating innovation, we add R\&D intensity to the set of controls. Model 2 in Table 6 shows that state stock concentration is still positive and significant after we control for R\&D intensity, implying state ownership concentration increases the effectiveness of firms in generating innovation.

For central government ownership, the results show that there is a positive relationship between central government ownership and R\&D investment and the associated coefficient is statistically significant at the $1 \%$ level, suggesting that firms affiliated with central government are more likely to invest in R\&D project and supporting Hypothesis 2a. In terms of innovation performance, the results provide a positive and significant relationship between central government ownership and innovation performance, which supports Hypothesis 3a. After we control for R\&D intensity, the coefficient for central government ownership is still positive and significant at the $1 \%$ level. Consequently, stateowned enterprises affiliated with the central government are the key drivers for firms' innovation activities.

For local government ownership, the coefficient is positive but statistically significant at the $5 \%$ level, indicating that firms affiliated with local government is more likely to invest in risky $R \& D$ project without supporting Hypothesis $2 b$. But the associated coefficient is much smaller than that for central government ownership, implying that firms affiliated with local government are less likely to invest in risky R\&D project than those affiliated with central government. In contrast, for innovation performance, the coefficient on the local government ownership is negative and statistically significant at the $5 \%$ level after controlling for R\&D intensity, which predicts that firms affiliated with local government are less capable to generate new products. This result supports Hypothesis 3b. Thus, local government ownership tends to decrease the effectiveness of firms in generating innovation.

For private ownership, the results show that consistent with Hypothesis 4a, private ownership is negatively related with R\&D expenditure and the coefficient is statistically significant at the $1 \%$ level, which predicts that privately held firms have insufficient resources for R\&D activities. Likewise, private ownership is also negatively and significantly associated with innovation performance, which is in line with Hypothesis $4 \mathrm{~b}$. After we control for R\&D intensity, private ownershipfurther decreases the effectiveness of firms in generating innovation.

\section{Robustness checks}

We conducted several sensitivity tests to ensure the robustness of our results. First, we tried alternative measures of ownership types using ownership shares, i.e., the percentages of central state capital, local state capital, private capital, and foreign capital. According to registration codes of ownership types, we calculated ownership shares for each category using the capital share. In doing so, we can ensure the consistency of dummies measures of ownership types with capital share measures without specifying the threshold level for ownership categories. The results are qualitatively unchanged. 
Second, we divided our sample into subsamples to test the robustness of our results in accordance with ownership types. We tested the effects of state ownership (a dummy that equals to one if state-owned) on R\&D intensity and innovation performance in the subsample that only includes SOEs and POEs (i.e., SOEs vs. POEs), and the results show that state ownership has significant and positive effects on both innovation measures. In addition, we tested the effects of central SOEs on R\&D intensity and innovation performance in the subsample that only includes SOEs (i.e., central SOEs vs. local SOEs), and the results show that central SOEs has significant and positive effects on both innovation measures. The results are consistent with our hypotheses.

Third, we used panel data methods to control for the estimation bias associated with unobserved firm-level heterogeneity. The choice between fixed and random effects models is reliant upon whether the unobserved individual effects correlate with the observed explanatory variables. The Hausman test can be used to distinguish between the two methods, of reasons. First, it is more appropriate to treat unobserved effects as randomly distributed over time for each individual firm in large samples (Nieto and Rodriguez 2011). Our sample drawn from large samples represents about $90 \%$ of total output in the majority of industries and the random-effects model is favored. Second, ownership type variables are dummies and the use of fixed-effects model will remove the effect of ownership types on innovation. Finally, fixed-effects estimates are biased when the time span is relatively short (Nieto and Rodriguez 2011). Since our sample span three years only, we applied the random effects model. The results are largely consistent.

Finally, the Chinese central government tends to retain control over more innovative and productive state owned enterprises in the process of economic reform and privatization, and state ownership might be reversely influenced by innovation, raising the potential endogenous problem (Lee and O'Neill 2003). We employed an instrumental variable method via the two-step GMM approach to address the potential endogeneity. The GMM estimator can be applied effectively in the econometric context of endogenous variables and heterogeneity. The proper choice of instruments should fulfill the conditions of relevance and exogeneity, i.e., strongly related to endogenous variables but unrelated to the error term (Bascle 2008). We follow Lee and O'neil (2003) and choose firm age and firm size as instruments. First, the market-oriented reform from the 1980s enables the government involvement to be always endogenous in China's transitional period. In particular, the 1980s ownership structure reform and the 1990s "letting go of the small" policy make firm age and size closely related to government involvement ( $\mathrm{Li}$ and Putterman 2008). We checked F-statistic in the first stage and found that both instruments are highly relevant (i.e., at the $1 \%$ significance level). Second, we performed Wu-Hausman test of endogeneity and the results show that we can reject the null hypothesis of exogeneity at the $1 \%$ significance level, indicating that state stock concentration and central government ownership are endogenous. Third, we employed the difference-in-Sargan test for instrument exogeneity and the result is not significant, suggesting both instruments are exogenous (Bascle 2008). Additionally, we conducted instrument redundancy test to ensure that both instruments are appropriate. The results support our choice at the $1 \%$ significance level. Since we used firm size as an instrumental variable, we added capital stock in logarithm to the set of controls to tackle the scale effect. The results from GMM are reported in Tables 7 and 8. 
Table 7 Hierarchical analyses of ownership and R\&D intensity: IV GMM estimation

\begin{tabular}{|c|c|c|}
\hline & \multicolumn{2}{|c|}{ R\&D expenditure/Sales } \\
\hline & Model 1 & Model 2 \\
\hline \multicolumn{3}{|l|}{ Independent variables } \\
\hline \multirow[t]{2}{*}{ State stock concentration } & $0.003^{* * *}$ & \\
\hline & $(0.001)$ & \\
\hline \multirow[t]{2}{*}{ Private stock concentration } & $-0.001^{* * *}$ & \\
\hline & $(0.001)$ & \\
\hline \multirow[t]{2}{*}{ Central SOEs } & & $0.013^{* * *}$ \\
\hline & & $(0.002)$ \\
\hline \multirow[t]{2}{*}{ Local SOES } & & $0.001^{* *}$ \\
\hline & & $(0.000)$ \\
\hline \multirow[t]{2}{*}{ POEs } & & $-0.001^{* * *}$ \\
\hline & & $(0.000)$ \\
\hline \multicolumn{3}{|l|}{ Control variables } \\
\hline \multirow[t]{2}{*}{ Capital stock } & $0.001^{* * *}$ & $0.001^{* * *}$ \\
\hline & $(0.000)$ & $(0.000)$ \\
\hline \multirow[t]{2}{*}{ Foreign ownership } & $-0.001^{* * *}$ & $-0.001^{* * *}$ \\
\hline & $(0.000)$ & $(0.000)$ \\
\hline \multirow[t]{2}{*}{ Leverage } & $-0.001^{* * *}$ & $-0.001^{* * *}$ \\
\hline & $(0.000)$ & $(0.000)$ \\
\hline \multirow[t]{2}{*}{ Employee training } & $0.335^{* * *}$ & $0.265^{* *}$ \\
\hline & $(0.105)$ & $(0.106)$ \\
\hline \multirow[t]{2}{*}{ Capital intensity } & -0.000 & -0.000 \\
\hline & $(0.000)$ & $(0.000)$ \\
\hline \multirow[t]{2}{*}{ Return to assets } & $0.001^{* * *}$ & $0.001^{* * *}$ \\
\hline & $(0.000)$ & $(0.000)$ \\
\hline Industry dummy & Yes & Yes \\
\hline Region dummy & Yes & Yes \\
\hline Year dummy & Yes & Yes \\
\hline$N$ & 465003 & 465003 \\
\hline Endogeneity test & $6.57^{* * *}$ & $53.08^{* * *}$ \\
\hline Instrument redundancy test & $4647.96^{* * *}$ & $1232.48^{* * *}$ \\
\hline
\end{tabular}

** and ${ }^{* * *}$ are significantly different from zero at the $5 \%$ and $1 \%$ level respectively

They show that all key results remain unchanged compared to Tobit estimator except for local government ownership. Although the coefficient for local government ownership is positively and significantly related with innovation performance, the magnitude of the coefficient is much smaller than the one for central government ownership.

\section{Discussion and conclusion}

Discussions

This paper investigates how ownership structure and ownership types influence firm level R\&D intensity and innovation performance in transitional China. We argue that the diversity of government ownership and R\&D activities emerged from the process of insitutional changes (i.e., fiscal and SOE reforms). 
Table 8 Hierarchical analyses of ownership and innovation performance: IV GMM estimation

\begin{tabular}{|c|c|c|c|c|}
\hline & \multicolumn{4}{|c|}{ New product sales/Sales } \\
\hline & Model 1 & Model 2 & Model 3 & Model 4 \\
\hline \multicolumn{5}{|l|}{ Independent variables } \\
\hline \multirow[t]{2}{*}{ State stock concentration } & $0.053^{* * *}$ & $0.057^{* * *}$ & & \\
\hline & $(0.006)$ & $(0.006)$ & & \\
\hline \multirow[t]{2}{*}{ Private stock concentration } & $-0.006^{* * *}$ & $-0.004^{* * *}$ & & \\
\hline & $(0.001)$ & $(0.001)$ & & \\
\hline \multirow[t]{2}{*}{ Central SOEs } & & & $0.260^{* * *}$ & $0.265^{* * *}$ \\
\hline & & & $(0.021)$ & $(0.021)$ \\
\hline \multirow[t]{2}{*}{ Local SOEs } & & & $0.006^{* * *}$ & $0.007^{* * *}$ \\
\hline & & & $(0.002)$ & $(0.002)$ \\
\hline \multirow[t]{2}{*}{ POES } & & & $-0.006^{* * *}$ & $-0.005^{* * *}$ \\
\hline & & & $(0.001)$ & $(0.001)$ \\
\hline \multicolumn{5}{|l|}{ Control variables } \\
\hline \multirow[t]{2}{*}{$R \& D$ intensity } & & $1.706^{* * *}$ & & $1.645^{* * *}$ \\
\hline & & $(0.078)$ & & $(0.077)$ \\
\hline \multirow[t]{2}{*}{ Capital stock } & $0.010^{* * *}$ & $0.009^{* * *}$ & $0.009^{* * *}$ & $0.009^{* * *}$ \\
\hline & $(0.000)$ & $(0.000)$ & $(0.000)$ & $(0.000)$ \\
\hline \multirow[t]{2}{*}{ Foreign ownership } & $-0.007^{* * *}$ & $-0.005^{* * *}$ & $-0.007^{* * *}$ & $-0.004^{* * *}$ \\
\hline & $(0.001)$ & $(0.001)$ & $(0.001)$ & $(0.001)$ \\
\hline \multirow[t]{2}{*}{ Leverage } & $-0.002^{* *}$ & $-0.002^{* * *}$ & $-0.003^{* * *}$ & $-0.002^{* * *}$ \\
\hline & $(0.001)$ & $(0.001)$ & $(0.001)$ & $(0.001)$ \\
\hline \multirow[t]{2}{*}{ Employee training } & -0.001 & $-0.138^{*}$ & -0.046 & $-0.296^{* * *}$ \\
\hline & $(0.033)$ & $(0.071)$ & $(0.045)$ & $(0.081)$ \\
\hline \multirow[t]{2}{*}{ Capital intensity } & $-0.000^{* * *}$ & $-0.000^{* * *}$ & $-0.000^{* * *}$ & $-0.000^{* * *}$ \\
\hline & $(0.000)$ & $(0.000)$ & $(0.000)$ & $(0.000)$ \\
\hline \multirow[t]{2}{*}{ Return to assets } & $0.007^{* * *}$ & $0.006^{* * *}$ & $0.006^{* * *}$ & $0.006^{* * *}$ \\
\hline & $(0.001)$ & $(0.001)$ & $(0.001)$ & $(0.001)$ \\
\hline Industry dummy & Yes & Yes & Yes & Yes \\
\hline Region dummy & Yes & Yes & Yes & Yes \\
\hline Year dummy & Yes & Yes & Yes & Yes \\
\hline N & 465003 & 459147 & 465003 & 459147 \\
\hline Endogeneity test & $57.57^{* * *}$ & $69.89 * * *$ & $128.43^{* * *}$ & $145.89^{* * *}$ \\
\hline Instrument redundancy test & $4647.96^{* * *}$ & $4518.90^{* * *}$ & $1233.19^{* * *}$ & $1205.64^{* * *}$ \\
\hline
\end{tabular}

** and *** are significantly different from zero at the $5 \%$ and $1 \%$ level respectively

Our results suggest that central government ownership is benefitical for R\&D activities in transitional China following the ecnonomic reforms. However, our findings on negative effects of local government ownership and private ownership on R\&D intensity and innovation performance suggest disparate results from prior studies of ownership and innovation in China. We begin to explain the reasons why central government ownership would differ from local government ownership under China's changing institutional context. Notably, our empirical results lead to new classification about state ownership from the corporate strategy literature, which conventionally considers state ownership as a universal ownership type. We argue and indeed find that central government-owned firm is more likely to undertake risky R\&D investment. The prior 
literature indicated that soft budget constraint is an important catalyst for R\&D investment because softer budget provides sufficient funds for firms to have confidence even in circumstances of uncertainty (Nohria and Gulati 1996). Conversely, firms with hard budget constraint are less likely to pursue risky R\&D investment. In prior research, scholars have used state ownership reflecting one ownership type (Jefferson et al. 2003; Li and Xia 2008), suggesting that such ownership is negatively related to R\&D intensity. Our results raise the question about the effects of China's institutional changes on the divergence of SOEs in terms of the resource allocation and therefore suggest that central government and local government would have different risktaking attributes.

Secondly, we find that concentrated state ownership is positively related to firm's R\&D intensity and innovation performance. The literature on firm innovation, inspired largely by agency theory (Jensen and Meckling 1976), indicating that concentrated ownership plays positive roles in monitoring managers' behaviours. Our results are consistent with prior corporate governance studies (Hoskisson et al. 1994) and advocate that ownership concentration reduces agency costs and improves R\&D intensity and innovation performance. In particular, our results reflect the important role of the government in transitional economies in terms of R\&D activities. Arens and Brouthers (2001) suggest that key stakeholders normally are the state governments when a country is transiting from a planned economy to a market economy. Being the key and large shareholder, the state government can not only play a critical leadership and monitoring role, but also offer valuable resources to its owned firms in order to facilitate innovation.

By contrast, we found a negative relationship between private ownership concentration and firms' R\&D intensity and innovation performance. It is not a surprising result because of the nature of the private ownership concentration. Compared to government ownership where the "real owner" is normally one legal entity, private owners can be a list of individual owners with very unequal share ownership and varied interests. Corporate governance literature has documented that large shareholder is an effective monitoring mechanism while small shareholder is usually free riders. Thus, the private ownership concentration means a combined private ownership from individual owners, rather than a reflection of monitoring incentive and control power.

Finally, our results indicate a negative relationship between private ownership and firm's R\&D intensity and innovation performance. The result is not surprising giving the fact that privately owned firms tend to be undercapitalized in China. Resources often act as the prerequisite to take risky strategic choices (Cyert and March 1963). China's government however intervenes heavily in financial allocations in order to achieve the targeted economic growth rate. Policy loans, rather than commercial loans, accounted for a large portion of credit by banks. Privately owned firms have been placed at the bottom of the lending list of state-owned banks. Firth et al. (2009) found that having government ownership or political connection helps privately owned firms to gain access to bank finance. Furthermore, transitional economies in general have less developed institutional framework, which in turn create barriers for firms to invest in R\&D and innovation. A sophisticated property IPRs system can provide protection against illegal expropriation and imitation and hence secure financial returns on R\&D. Private firms are less likely to invest in risky R\&D under a poorly developed IPR system because financial and legal costs of imitating a patented product/service is low in 
transitional China. Therefore, insufficient funding, plus less favorable institutional settings, discourage privately owned firms to take risk and seek R\&D investment.

\section{Implications}

Our findings firstly alert managers, investors and policy makers to take into account the importance of the changing institutional environment on firm's $R \& D$ activities. China's institutional reforms produced different levels of state owners with different abilities to gain access to resources. Such institutionalized resource allocation patterns can either help organizations to generate new innovations or they can produce investment myopia and rigidity. Continuity in resource allocation attracts R\&D because such investment is long horizon and hardly receives payoffs in the interim period. Being the large block shareholder, the central government has an obligation to deliver stable current returns and also make long-term investments to ensure future profitability. Although the block shareholder nature resorts to activism to maximize long-term value, the local government has to adapt to their lack of capital availability and engage in short-term investments. Our results reflect previous studies which suggest that central government fosters long-term investments while local government is associated with short-term financial gains (Teng 2012).

Additionally, recognition of the increasing importance of the government in R\&D investments has reopened the debate on whether state ownership damages firm performance. Conventional studies have suggested the negative impact of state ownership on firm performance, and predicted that the Chinese government should continue to dilute its ownership proportion in order to further improve performance. However, our results showed that state ownership is not prerequisite for these underperformed firms. Rather, central government ownership would be highly beneficial for firms in the long term. In contrast, local government officials and managers under this ownership category, who are assessed on the basis of annual performance measures, often cannot to take long views in their investment decision.

\section{Limitations and future research directions}

This study suggests a number of opportunities for future research. One avenue of research would be to focus on the impacts of ownership types on innovation effectiveness, perhaps by looking at the linkage between corporate governance and R\&D efficiency, i.e., based on input-output formula. Secondly, further research can develop alternative measures of innovation performance. Previous studies usually measured innovation performance of firms by using number of patent. However, Choi et al. (2011) indicate that not all firms protect their technological assets and innovation outputs with patents. In this study, we measured innovation performance using new product sales over total sales. Nevertheless, new product may not be the result of firm's own innovation. Some firms may purchase technical know-how as alternative implement to internal research and development. Third, although we concentrated on firms in China, our findings on the pattern of resource availability and firm innovation might apply for emerging firms in other transitional economies. Thus, this study contributes to pertinent discussion on the leveraging of organizational resources to enhance performance through the adaptation and enactment of strategies in competitive environments. 
Future researchers need to explore the generalizability of our findings by conducting studies in other emerging and transitional nations. Future studies can also leverage our findings to provide comprehensive behavioural explanations for the patterns and temporal dynamism in the generation and deployment of slack resources to achieve organizational goals. Finally, our sample only covers 2005-2007. Government policy and industrial environment may have dramatic changes after our examination period. The Chinese government is maturing its formal institutions. For example, China has made extensive progress in joining international IPR convections; passing domestic IPR laws, establishing registration and enforcement. All of such institutional changes may alter the incentive for privately-owned firms to make R\&D investment. Our findings on the encouraging role of central SOEs on R\&D might also have shifts after 2007. The results should be interpreted in specific institutional contexts and further studies could extend our analyses along this line of research.

\section{Acknowledgements}

This research is supported by National Natural Science Foundation of China (grant no. 71373010).

Authors' contributions

Both authors read and approved the final manuscript.

Competing interests

The authors declare that they have no competing interests.

\section{Publisher's Note}

Springer Nature remains neutral with regard to jurisdictional claims in published maps and institutional affiliations.

\section{Author details}

${ }^{1}$ Coventry Business School, Coventry University, Priory Street, Coventry CV1 5FB, UK. ${ }^{2}$ School of Business, Renmin University of China, Beijing 100872, China.

Received: 20 April 2016 Accepted: 20 January 2017

Published online: 05 June 2017

\section{References}

Aguilera, R., Filatotchev, I., Gospel, H., \& Jackson, G. (2008). An organizational approach to comparative corporate governance: costs, contingencies, and complementarities. Organization Science, 19(3), 475-492.

Arens, P., \& Brouthers, K. D. (2001). Key stakeholder theory and state owned versus privatized firms. Management International Review, 41(4), 377-394.

Ballot, G., Fakhfakh, F., \& Taymaz, E. (2006). Who benefits from training and R\&D: the firm or the workers? British Journal of Industrial Relations, 44(3), 473-495.

Bascle, G. (2008). Controlling for endogeneity with instrumental variables in strategic management research. Strategic Organization, 6(3), 285-327.

Belloc, F. (2012). Corporate governance and innovation: a survey. Journal of Economic Surveys, 26(5), 835-864.

Berchicci, L. (2013). Towards an open R\&D system: Internal R\&D investment, external knowledge acquisition and innovative performance. Research Policy, 42(1), 117-127.

Cassiman, B., \& Veugelers, R. (2006). In search of complementarity in innovation strategy: internal R\&D and external knowledge acquisition. Management Science, 52(1), 68-82.

Chang, S. J., Chung, C., \& Mahmood, I. P. (2006). When and how does business group affiliation promote firm innovation? A tale of two emerging economies. Organization Science, 17(5), 637-656.

Chen, W. R., \& Miller, K. D. (2007). Situational and institutional determinants of firms' R\&D search intensity. Strategic Management Journal, 28(4), 369-381.

Chen, V. Z., Li, J., \& Shapiro, D. M. (2011). Are OECD-prescribed "Good Corporate Governance Practices" really good in an emerging economy? Asia Pacific Journal of Management, 28(1), 115-138.

Chen, V. Z., Li, J., Shapiro, D. M., \& Zhang, X. (2014). Ownership structure and innovation: an emerging market perspective. Asia Pacific Journal of Management, 31(1), 1-24.

Choi, S. B., Lee, S. H., \& Williams, C. (2011). Ownership and firm innovation in a transition economy: evidence from China. Research Policy, 40(3), 441-452.

Choi, S. B., Park, B. I., \& Hong, P. (2012). Does ownership structure matter for firm technological innovation performance? The case of Korean firms. Corporate Governance: An International Review, 20(3), 267-288.

Cyert, R. M., \& March, J. (1963). A behavioral theory of the firm. Englewood Cliffs: Prentice-Hall.

Davidson, C., \& Segerstrom, P. (1998). R\&D subsidies and economic growth. RAND Journal of Economics, 29(3), 548-577.

Escribano, A., Fosfuri, A., \& Tribo, J. A. (2009). Managing external knowledge flows: the moderating role of absorptive capacity. Research Policy, 38(1), 96-105. 
Estrin, S., Baghdasaryan, D., \& Meyer, K. E. (2009). Institutional distance and human resource distance in international business strategies in emerging economies. Journal of Management Studies, 46(7), 1171-1196.

Filatotchev, I., Stephan, J., \& Jindra, B. (2008). Ownership structure, strategic controls and export intensity of foreigninvested firms in transition economies. Journal of International Business Studies, 39(7), 1133-1148.

Firth, M., Lin, C., Liu, P., \& Wang, S. (2009). Inside the black box: Bank credit allocation in China's private sector. Journal of Banking \& Finance, 33(6), 1143-1155.

Greve, H. R. (2003). A behavioral theory of R\&D expenditures and innovations: evidence from shipbuilding. Academy of Management Journal, 46(6), 685-702.

Hoskisson, R. E., Johnson, R., \& Moesel, D. D. (1994). Corporate divestiture intensity in restructuring firms: effects of governance, strategy, and performance. Academy of Management Journal, 37(5), 1207-1251.

Hoskisson, R. E., Hitt, M. A., Johnson, R. A., \& Grossman, W. (2002). Conflicting voices: the effects of institutional ownership heterogeneity and internal governance on corporate strategies. Academy Management Journal, 45(4), 607-716.

Jefferson, G., Hu, A. G. Z., Guan, X., \& Yu, X. (2003). Ownership, performance, and innovation in China's large and medium-size industrial enterprise sector. China Economic Review, 14(1), 89-113.

Jensen, M., \& Meckling, W. (1976). Theory of the firm: Managerial behaviours, agency cost and ownership structure. Journal of Financial Economics, 3(4), 305-360.

Kafouros, M., Wang, C., Piperopoulosa, P., \& Zhang, M. (2015). Academic collaborations and firm innovation performance in China: the role of region-specific institutions. Research Policy, 44(3), 803-817.

Kim, H., Kim, H., \& Lee, P. (2008). Ownership structure and the relationship between financial slack and R\&D investments: Evidence from Korean firms. Organization Science, 19(3), 404-418.

Kornai, J. (1992). The socialist system: the political economy of communism. Princeton: Princeton University Press.

Kornai, J., Maskin, E., \& Roland, G. (2003). Understanding the soft budget constraint. Journal of Economic Literature, 41(4), 1095-1136.

La Croix, S. J., \& Konan, D. E. (2002). Intellectual property rights in China: the changing political economy of ChineseAmerican interests. World Development, 25(6), 759-788.

La Porta, R., Lopez-de-Silanes, F., Shleifer, A., \& Vishny, R. (2000). Investor protection and corporate governance. Journal of Financial Economics, 58(1), 3-27.

Lee, P. M., \& O'Neill, H. M. (2003). Ownership structures and R\&D investments of U.S. and Japanese firms: agency and stewardship perspectives. Academy of Management Journal, 46(2), 212-225.

Leiponen, A., \& Helfat, C. E. (2010). Innovation objectives, knowledge sources, and the benefits of breadth. Strategic Management Journal, 31(2), 224-236.

Lejeune, J. (2014). Weak enforcement of intellectual property rights in China: integrating political, cultural and structural explanations. Journal of Contemporary China, 23(88), 698-714.

Li, W., \& Putterman, L. (2008). Reforming China's SOEs: an overview. Comparative Economic Studies, 50(3), 353-380.

Li, S., \& Xia, J. (2008). The role and performance of state firms and non-state firms in China's economic transition. World Development, 36(1), 39-54.

Li, H., Meng, K., Wang, Q., \& Zhou, L. A. (2013). Political connections, financing and firm performance: evidence from Chinese private firms. Journal of Development Economics, 87(2), 283-299.

Liu, G. S., Sun, P., \& Woo, W. T. (2006). The political economy of Chinese-style privatization: motives and constraints. World Development, 34(12), 2016-2033.

Love, J. H., Roper, S., \& Du, J. (2009). Innovation, ownership and profitability. International Journal of Industrial Organization, 27(3), 424-434.

Luo, Y., \& Yao, J. (2006). Impact of state ownership and control mechanisms on the performance of group affiliated companies in China. Asia Pacific Journal of Management, 23(4), 485-503.

Luo, Y., Xue, Q., \& Han, B. (2010). How emerging market governments promote outward FDI: experience from China. Journal of World Business, 45(1), 68-79.

Maskin, E. S. (1999). Recent theoretical work on the soft budget constraint. American Economic Review, 89(2), 421-425.

Meyer, K. E., \& Peng, M. W. (2016). Theoretical foundations of emerging economy business research. Journal of International Business Studies, 47(1), 3-22.

Molas-Gallart, J., \& Tang, P. (2006). Ownership matters: intellectual property, privatization and innovation. Research Policy, 35(2), 200-212.

Montinola, G., Qian, Y., \& Weingast, B. R. (1995). Federalism Chinese style: the political basis for economic success in China. World Politics, 48(01), 50-81.

Musacchio, A., \& Lazzarini, S. G. (2014). Reinventing state capitalism: Leviathan in business, Brazil and beyond. Cambridge: Harvard University Press.

Naughton, B. (2008). SASAC and rising corporate power in China. China Leadership Monitor, 24(2), 1-9.

Neter, J., Wasserman, W., \& Kutner, M. H. (1985). Applied linear statistical models. Homewood: Irwin.

Nieto, M. J., \& Rodriguez, A. (2011). Offshoring of R\&D: looking abroad to improve innovation performance. Journal of International Business Studies, 42(3), 345-361.

Nohria, N., \& Gulati, R. (1996). Is slack good or bad for innovation? Academy of Management Journal, 39(5), 1245-1264.

Nohria, N., \& Gulati, R. (1997). What is the optimum amount of organizational slack? A study of the relationship between slack and innovation in multinational firms. European Management Journal, 15(6), 603-611.

North, D. C. (1990). Institutions, institutional change, and economic performance. Cambridge: Harvard University Press.

Pei, M. (2002). China's governance crisis. Foreign Affairs, 81(5), 96-109.

Peng, M. W. (2003). Institutional transitions and strategic choices. Academy of Management Review, 28(2), 275-296.

Peng, M. W., \& Heath, P. S. (1996). The growth of the firm in planned economies in transition: institutions, organizations, and strategic choice. Academy of Management Review, 21(2), 492-528.

Peng, M. W., Wang, D. Y., \& Jiang, Y. (2008). An institution-based view of international business strategy: a focus on emerging economies. Journal of International Business Studies, 39(5), 920-936.

Pisano, G. (2006). Profiting from innovation and the intellectual property revolution. Research Policy, 35(8), 1122-1130.

Qi, J. C. (1995). The role of the local government in China's transitional economy. The China Quarterly, 144(4), 1132-1149. 
Qi, D., Wu, W., \& Zhang, H. (2000). Shareholding structure and corporate performance of partially privatized firms: evidence from listed Chinese companies. Pacific-Basin Finance Journal, 8(5), 587-610.

Qian, Y. (1996). Enterprise reform in China: agency problem and political control. The Economics of Transition, 4(2), 427-447.

Qian, Y., \& Roland, G. (1998). Federalism and the soft budget constraint. American Economic Review, 88(5), 1143-1162.

Scott, W. R. (1995). Institutions and organizations. Thousand Oaks: Sage.

Sheng, S., Zhou, K. Z., \& Li, J. J. (2011). The effects of business and political ties on firm performance: evidence from China. Journal of Marketing, 75(1), 1-15.

Souder, D., \& Shaver, J. M. (2010). Constraints and incentives for making long horizon corporate investments. Strategic Management Journal, 31(12), 1316-1336.

Stan, C. V., Peng, M. W., \& Bruton, G. D. (2014). Slack and the performance of state-owned enterprises. Asia Pacific Journal of Management, 31(2), 473-495.

Sun, Q., \& Tong, W. H. S. (2003). China share issue privatization: the extent of its success. Journal of Financial Economics, 70(2), 183-222.

Sun, Q., Tong, W., \& Tong, J. (2002). How does government ownership affect firm performance? Evidence from China's privatization experience. Journal of Business Finance and Accounting, 29(1-2), 1-28.

Tan, L. H., \& Wang, J. (2007). Modelling an effective corporate governance system for China's listed state-owned enterprises: issues and challenges in a transitional economy. Journal of Corporate Law Studies, 7(1), 143-184.

Teng, D. (2012). Fiscal reform, ownership restructuring, and corporate objective in Chinese state-owned enterprises. In L. Wang (Ed.), Rising China in the changing world economy. London: Routledge.

Tihanyi, L., Johnson, R. A., Hoskisson, R. E., \& Hitt, M. A. (2003). Institutional ownership differences and international diversification: the effects of boards of directors and technological opportunity. Academy of Management Journal, 46(2), 195-211.

Tobin, J. (1958). Estimation of relationships for limited dependent variables. Econometrica, 26(1), 24-36.

Tsai, K.-H. (2009). Collaborative networks and product innovation performance: toward a contingency perspective. Research Policy, 38(5), 765-778.

Wang, J., Guthrie, D., \& Xiao, Z. (2012). The rise of SASAC: asset management, ownership concentration, and firm performance in China's capital markets. Management and Organization Review, 8(2), 253-281.

Wang, C., Hong, J., Kafouros, M., \& Wright, M. (2012). Exploring the role of government involvement in outward direct investment from emerging economies. Journal of International Business Studies, 43(7), 655-676.

White, H. (1980). A heteroscedasticity consistent covariance matrix estimator and a direct test for heteroscedasticity. Econometrica, 48(4), 817-838.

Wiersema, M. F., \& Bowen, H. P. (2008). Corporate diversification: the impact of foreign competition, industry globalization, and product diversification. Strategic Management Journal, 29(2), 115-132.

Wooldridge, J. M. (2013). Introductory econometrics - A modern approach. Mason: South-Western Cengage Learning.

Wright, P., Ferris, S. P., Sarin, A., \& Awasthi, V. (1996). Impact of corporate insider, blockholder, and institutional equity ownership on firm risk taking. Academy of Management Journal, 39(2), 441-458.

Yam, C. M., Guan, J. C., Pun, K. F., \& Tam, P. Y. (2004). An audit of technological innovation capabilities in Chinese firms: some empirical findings in Beijing, China. Research Policy, 33(8), 1123-1250.

Yi, J., Wang, C., \& Kafouros, M. (2013). The effects of innovative capabilities on exporting: do institutional forces matter? International Business Review, 22(2), 392-406.

Yiu, D. W., Su, J., \& Xu, Y. (2013). Alternative financing and private firm performance. Asia Pacific Journal of Management, 30(3), 829-852.

Young, M. N., Peng, M. W., Ahlstrom, D., Bruton, G. D., \& Jiang, Y. (2008). Corporate governance in emerging economies: a review of the principal-principal perspective. Journal of Management Studies, 45(1), 1196-1220.

Yueh, L. Y. (2009). Patent laws and innovation in China. International Review of Law and Economics, 29(4), 304-313.

Zeng, S. X., Xie, X. M., \& Tam, C. M. (2010). Relationship between cooperation networks and innovation performance of SMEs. Technovation, 30(3), 181-194.

Zhang, L. Y. (1999). Chinese central-provincial fiscal relationships, budgetary decline and the impact of the 1994 fiscal reform: an evaluation. The China Quarterly, 157(1), 115-141.

Zhang, L. (2015). Refining the art of reforming the corporate governance of Chinese state-controlled listed companies: venture capital and adaptive efficiency. Frontiers of Business Research in China, 9(2), 161-191.

Zhang, T., \& Zou, H.F. (1998). Fiscal decentralization, public spending, and economic growth in China. Journal of Public Economics, 67(2), 221-240

Zhang, A., Zhang, Y., \& Zhao, R. (2003). A study of the R\&D efficiency and productivity of Chinese firms. Journal of Comparative Economics, 31(3), 444-464.

Zhang, Y., Li, H., Hitt, M. A., \& Cui, G. (2007). R\&D intensity and international joint venture performance in an emerging market: moderating effects of market focus and ownership structure. Journal of International Business Studies, 38(6), 944-960.

Zhou, C. \& Li, J. (2008). Product innovation in emerging market-based international joint ventures: an organizational ecology perspective. Journal of International Business Studies, 39(7), 1114-1132.

Zhou, K. Z., Gao, G. Y., \& Zhao, H. (2016). State ownership and firm innovation in China: an integrated view of institutional and efficiency logics. Administrative Science Quarterly. doi:10.1177/0001839216674457. 